\title{
Association of 'Candidatus Phytoplasma cynodontis' with the yellow leaf disease of ivy gourd in Thailand
}

\author{
Anurag Sunpapao
}

Received: 17 February 2014 / Accepted: 5 March 2014 /Published online: 15 March 2014

(C) Australasian Plant Pathology Society Inc. 2014

\begin{abstract}
Ivy gourd (Coccinia grandis) is a small climbing perennial plant in the family Cucurbitaceae. The disease symptom of yellow leaves was observed frequently on ivy gourd in Hatyai, Songkhla, Thailand, during 2013. Infected tissue samples were assayed by nested PCR with the universal primer pair P1/P7, followed by $\mathrm{R} 16 \mathrm{~F} 2 \mathrm{n} / \mathrm{R} 2$ to amplify the $16 \mathrm{~S}$ rDNA fragment. The approximately $1.2 \mathrm{~kb}$ PCR products that were observed in symptomatic leaves had the highest nucleotide sequence similarity (99 \%) with the 16SrXIV group phytoplasmas. To the author's knowledge, this is the first report of ivy gourd as a host of 'Candidatus Phytoplasma cynodontis' in Thailand or elsewhere.
\end{abstract}

Keywords Coccinia grandis $\cdot$ Nested-PCR $\cdot$ Universal primer Yellow disease

Ivy gourd (Coccinia grandis), a member of Cucurbitaceae family, is a climbing perennial branched herb found in several parts of Thailand. This plant is grown for its edible young shoots and edible fruit in Southeast Asia (Linney 1986). It is not only amongst the main ingredients for Thai local cuisine, but ivy gourd is reported to have hepatoprotective activity against liver damage in rats, suggesting it may have pharmaceutical properties in humans (Kundu et al. 2012). In gardens at the Prince of Songkla University, Thailand, Ivy gourd plants showing symptoms of yellow leaves (Fig. 1) were observed during 2013. Such symptoms are commonly associated with plant pathogenic phytoplasmas.

\footnotetext{
A. Sunpapao $(\bowtie)$

Department of Pest Management, Faculty of Natural Resources, Prince of Songkla University, Hatyai, Songkhla 90112, Thailand e-mail: anurag.su@psu.ac.th
}

Phytoplasmas belong to Class Mollicutes and are prokaryotic microorganisms lacking cell walls that inhabit the phloem of plant vascular tissues (Bai et al. 2006). These pathogens are generally transmitted by leafhoppers in a persistent manner, and they replicate in the insect vector and the host plants (Lee et al. 1993, 2000; Suzuki et al. 2006). These pathogens induce a range of symptoms including yellowing, phyllody, proliferation, witches' broom and green flowers (Agrios 2005). Phytoplasmas are obligate parasitic pathogens that cannot be cultured in vitro; therefore, the precise diagnosis of these pathogens relies mainly on molecular analysis of $16 \mathrm{~S}$ rDNA conserved genes.

To determine whether phytoplasmas were associated with the yellow disease of ivy gourd, four symptomatic and one symptomless leaves were collected. The leaf midribs were excised and subjected to DNA extraction.

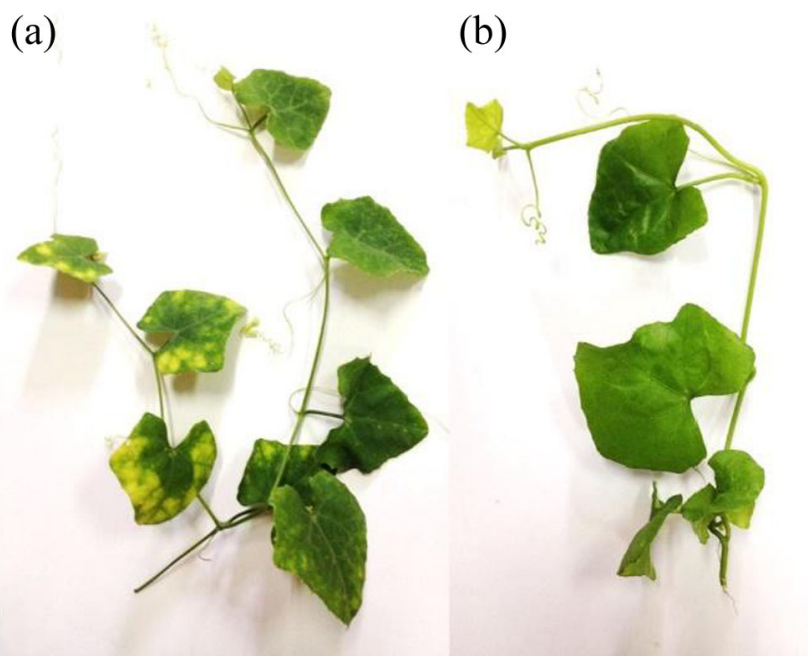

Fig. 1 Diseased leaves of ivy gourd showing yellow symptoms (a) and healthy plant (b) 


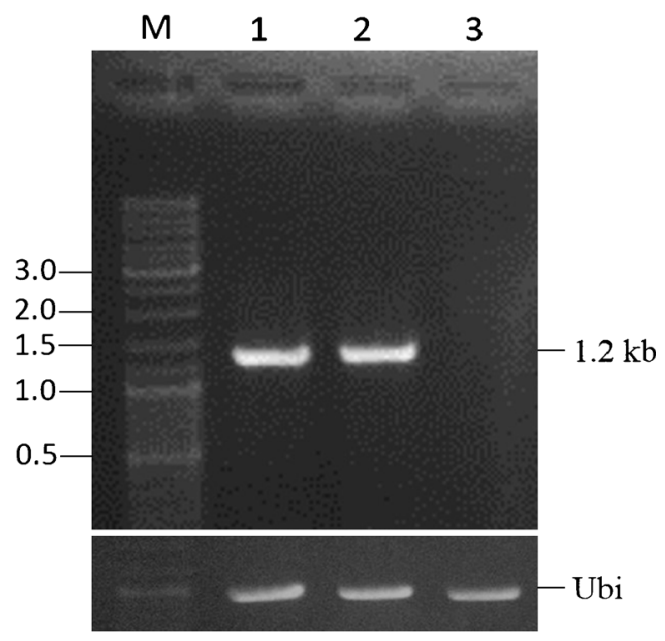

Fig. 2 Detection of phytoplasma by nested PCR with R16F2n/R2 primers from infected plants. $M: 1 \mathrm{~kb}$ GeneRuler DNA ladder; lanes 1 and 2: yellow disease affected ivy gourd; lane 3: symptomless sample. Ubi: Ubiquitin gene

Total DNA from each sample was extracted by the cetyltrimethyl ammonium bromide (CTAB) method (Kollar et al. 1990). The phytoplasma 16S rDNA gene was amplified by nested polymerase chain reaction (PCR), using a BIO-RAD T100 ${ }^{\mathrm{TM}}$ Thermal Cycler (Bio-Rad,
Hercules, CA, USA). Phytoplasma-specific universal primers P1/P7 were used for the first round of PCR amplification (Deng and Hiruki 1991; Smart et al. 1996). The PCR was performed in $50 \mu$ l of reaction mixture containing 10 pmol of each primer, $2 \times$ DreamTaq Green PCR Master Mix (Thermo Scientific) and $50 \mathrm{ng}$ of template DNA. An initial denaturation step for $3 \mathrm{~min}$ at $95{ }^{\circ} \mathrm{C}$ was followed by 35 cycles of denaturation for $30 \mathrm{~s}$ at $95{ }^{\circ} \mathrm{C}$, annealing for $30 \mathrm{~s}$ at $50{ }^{\circ} \mathrm{C}$ and extension for $1 \mathrm{~min}$ at $72{ }^{\circ} \mathrm{C}$, with a final extension step of $10 \mathrm{~min}$ at $72{ }^{\circ} \mathrm{C}$. The product was diluted at 1:10 ratio in water and $2 \mu \mathrm{l}$ was used in nested-PCR as a template with primer pair R16F2n/R2 (Gundersen and Lee 1996). The PCR cycle profile was the same as for the first round PCR. The ubiquitin gene (Ubi) housekeeping gene fragment was used as the internal control via the specific forward primers UBI-1 (5' TCCAGGACAAGGAGGGTA TCC $\left.3^{\prime}\right)$ and reverse primer UBI-2 (5' TAGTCAGCCAAG GTCCTTCCAT 3'). The PCR products were visualized by agarose gel electrophoresis with the $1 \mathrm{~kb}$ GeneRuler DNA ladder (Thermo Scientific) used as a DNA size marker.

A PCR product band at approximately $1.2 \mathrm{~kb}$ was observed from all four symptomatic samples (see Fig. 2 for two representative examples), and no such band was

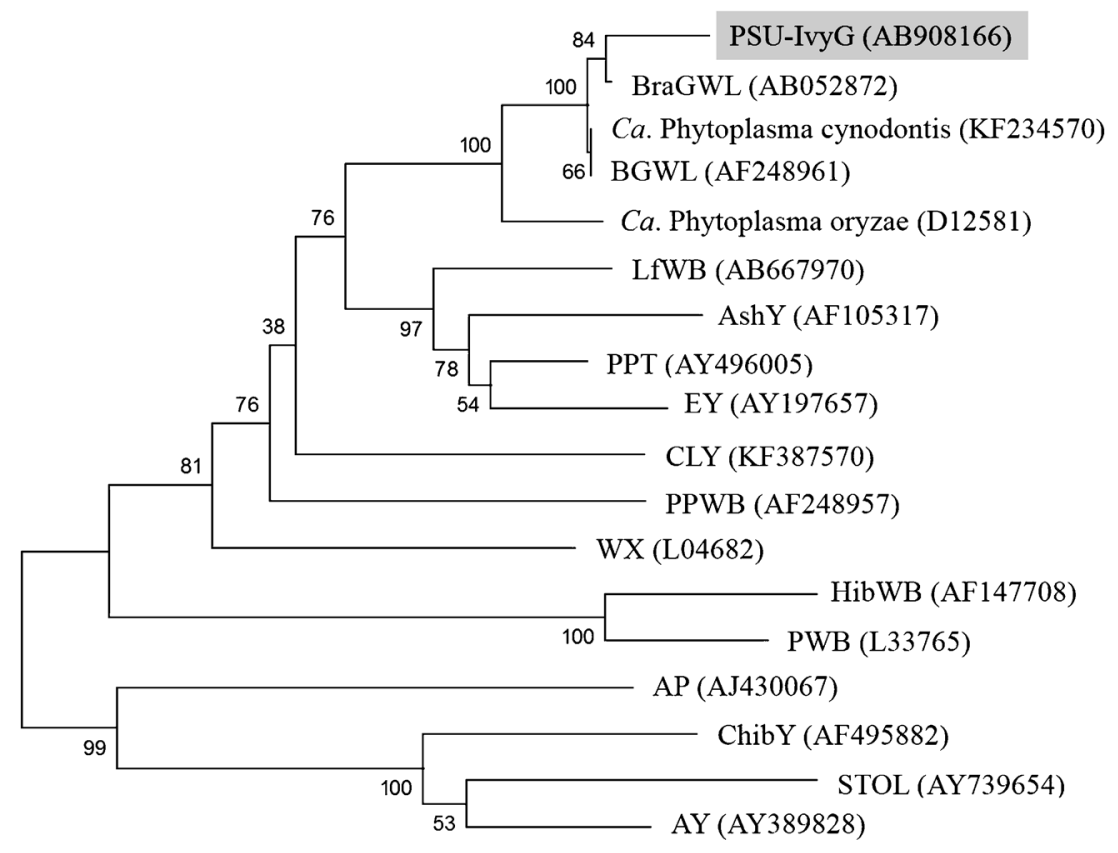

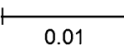

Fig. 3 Neighbor joining tree showing the genetic relationships of Thai yellow leaf disease of ivy gourd (PSU-IvyG) to 15 groups of phytoplasma, based on 16S rDNA sequences. Bootstrap values are shown on the branches. The GenBank accession numbers are shown in parentheses. Other abbreviations are as follows: BraWL, brachiaria grass white leaf; 'Ca. Phytoplasma cynodontis', 'Candidatus Phytoplasma cynodontis';
BGWL, Bermuda grass white leaf; ' $\mathrm{Ca}$. Phytoplasma oryzae', 'Candidatus Phytoplasma oryzae'; LfWB, loofah witches'-broom; AshY, ash yellows; PPT, potato purple top; EY, elm yellows; CLY, coconut lethal yellowing; PPWB, pigeon pea witches'-broom; WX, western X; HibWB, Hibiscus witches'-broom; PWB, peanut witches'-broom; AP, apple proliferation; ChibY, Chinaberry yellows; STOL, stolbur phytoplasma; AY, aster yellows 
found in the symptomless sample. Use of the ubiquitin gene confirmed this symptomless sample supported PCR (Fig. 2). The partial 16S rDNA gene region of one positive sample was bidirectionally sequenced at the Scientific Equipment Center, Prince of Songkla University, Songkhla, Thailand, by automated DNA sequencing with ABI Prism 377 (Applied Biosystems, USA) using the same primers as used in the PCR reaction. Using BLAST analyses, the sequence obtained was compared with sequences of phytoplasmas available in GenBank. The partial sequence of the $16 \mathrm{~S}$ rDNA region from a representative sample of ivy gourd, containing 1,188 bases, was deposited in GenBank and its accession number is AB908166. The BLAST analysis revealed $99 \%$ sequence similarity to several $16 \mathrm{SrXIV}$ groups with members of Brachiaria grass white leaf phytoplasma (AB052872) in Thailand, Bermuda grass white leaf in India (KF234570), in Myanmar (AB741630), and in Thailand (AB052871).

In order to visually assess the genetic relationships of Thailand yellow leaf phytoplasma, based on the $16 \mathrm{~S}$ rDNA sequences, phylogenetic and molecular evolutionary analyses were conducted using neighbor-joining with 1,000 bootstrap replicates on selected GenBank data. Figure 3 shows the similarity percentage values along with the phylogenetic tree for the conserved 16S rDNA nucleotide sequences, of the phytoplasma detected in ivy gourd in Thailand and of 15 other phytoplasmas. This nucleotide sequence analysis reveals that the phytoplasma detected in diseased ivy gourd in Thailand (PSU-IvyG) is closely related to Bermuda grass white leaf (BGWL) ('Candidatus Phytoplasma cynodontis') with over $99 \%$ identity, and so may be considered as being in the same 'Candidatus species' (IRPCM Phytoplasma/ Spiroplasma Working Team-Phytoplasma taxonomy group 2004). To the author's knowledge, this is the first report of the occurrence, symptomatology, and partial genetic characterization of a $16 \mathrm{SrXIV}$ phytoplasma associated with ivy gourd.
Acknowledgments The author would like to thank the Prince of Songkla University for funding and facilities. The copy-editing service of RDO/PSU and the helpful comments of Dr. Seppo Karrila are gratefully acknowledged.

\section{References}

Agrios GN (2005) Plant pathology, 5th edn. Elsevier Academic Press, San Diego, $922 \mathrm{p}$

Bai X, Zhang J, Ewing A, Miller SA, Radek AJ, Shevchenko D (2006) Living with genome instability: the adaptation of phytoplasmas to diverse environments of their insect and plant hosts. J Bacteriol 188: 3682-3696

Deng S, Hiruki C (1991) Amplification of 16S rRNA genes from culturable and nonculturable mollicutes. J Microbiol Methods 14:53-61

Gundersen DE, Lee IM (1996) Ultrasensitive detection of phytoplasmas by nested PCR assays using two universal primer pairs. Phytopathol Mediterr 35:144-151

IRPCM Phytoplasma/Spiroplasma Working Team-Phytoplasma Taxonomy Group (2004) 'Candidatus Phytoplasma', a taxon for the wall-less, non-helical prokaryotes that colonize plant phloem and insects. Int J Syst Evol Microbiol 54:1243-1255

Kollar A, Seemuler E, Bonnet F, Saillard C, Bove JM (1990) Isolation of the DNA of various plant pathogenic mycoplasma like organisms from infected plants. Phytopathology 80:233-237

Kundu M, Mazumder R, Kushwaha MD (2012) Evaluation of hepatoprotective activity of ethanol extract of Cocciniagrandis (L.) Voigt. leaves on experimental rats by acute and chronic models. Orient Pharm Exp Med 12:93-97

Lee IM, Hammond RW, Davis RE, Gundersen DE (1993) Universal amplification and analysis of pathogen $16 \mathrm{~S}$ rDNA for classification and identification of mycoplasma-like organisms. Phytopathology 83:834-842

Lee IM, Davis RE, Gundersen DE (2000) Phytoplasma: phytopathogenic mollicutes. Annu Rev Microbiol 54:221-255

Linney G (1986) Coccinia grandis (L) Voight: a new cucurbitaceous weed in Hawaii. Hawaii Bot Newsl 25:3-5

Smart CD, Schneider B, Blomquist CL, Guerra LJ, Harrison NA, Ahrens U, Lorenz K-H, Seemuller E, Kirkpatrick BC (1996) Phytoplasma-specific PCR primers based on sequences of the 16S-23S rRNA spacer region. Appl Environ Microbiol 62: 2988-2993

Suzuki S, Oshima K, Kakizawa S, Arashida R, Jung H, Yamaji Y (2006) Interaction between the membrane protein of a pathogen and insect microfilament complex determines insect-vector specificity. Proc Natl Acad Sci U S A 103:4252-4257 